Sciendoagreb International Review of Economics \& Business, Vol. 22, Special Conference Issue, pp. 107-123, 2019 (C) 2019 Faculty of Economics and Business, University of Zagreb and De Gruyter Open

All rights reserved. Printed in Croatia ISSN 1331-5609; UDC: $33+65$

DOI: 10.2478 /zireb-2019-0008

CONFERENCE PAPER

\title{
Examining Financial Management Practices in the Context of Smart ICT Use: Recent Evidence from Croatian Entrepreneurs
}

\author{
Bisera Karanovic** \\ Gordana Nikolic ${ }^{*}$ \\ Goran Karanovic ${ }^{* *}$
}

\begin{abstract}
Recent research demonstrates that entrepreneurs who learn contribute to lower failure rates of their startups. Nowhere is this more evident than in the area of financial management, where the entrepreneurs' lack of skills and competencies - and their willingness to acquire them - can be a critical factor to the success of the business venture. The purpose of this paper is to examine the financial management practices among Croatian entrepreneurs in relation to budgeting, raising capital, cash flow management, and the use of ICT tools for enhanced efficiency of their businesses. The survey was conducted on a sample of 58 entrepreneurs whose answers provide valuable insight into their grasp of financial concepts in the context of smart ICT use. The ensuing analysis of the level of proficiency in combining smart tools with financial management reveals increased adoption of ICT practices for budgeting and purchasing among Croatian entrepreneurs. Additionally, the findings indicate that the entrepreneurs' acquisition of skills and competencies for smart financial management presents a sound basis for increased overall financial sustainability of the startups.
\end{abstract}

Keywords: entrepreneurial finance; financial management; survey; smart ICT; Croatia

JEL Classification: G32, M15

\section{Introduction}

A common maxim defines entrepreneurship as the ability to turn ideas into action. This simple notion has engendered a universal goal for national governments to use

\footnotetext{
* Bisera Karanović and Gordana Nikolić are at PAR University College, Rijeka, Croatia.

** Goran Karanović is at University of Rijeka, Faculty of Tourism and Hospitality Management, Croatia.
} 
entrepreneurship as impetus for job creation, competitiveness and socio-economic development, since the rising number of entrepreneurs in the domestic economy could serve as a testament to successful policy making and an overall welfare improvement. Nevertheless, entrepreneurial preferences in the EU remain relatively low in comparison with the rest of the world. According to the European Commission, "only $37 \%$ of Europeans would like to be self-employed, compared to $51 \%$ of people in the US and China". Not only that, but self-employment has become a "less attractive prospect than in was in 2009 , when $45 \%$ of the population said they would rather be self-employed" (Flash Eurobarometer 354, 2012). Therefore, increasing entrepreneurial activity remains the 'holy grail' for policymakers and academics alike and can regularly be found at the top of the economic agendas of both Croatia and the European Union.

Building a successful and sustainable business from scratch requires a functional skillset, spanning over areas as diverse as creativity, risk-taking, innovation, management and interpersonal relations. While each of them may stand in its own right and claim equal - if not greater importance, relative to the others - a survey among small business owners revealed that the functional area they cited as "being the one in which they had the weakest skill was financial management, including accounting, bookkeeping, the raising of capital, and cash flow management" (Rogers, 2009). Relatively recently, however, ICT skills have captured the spotlight as digitalization is sweeping over all walks of business.

The purpose for writing this article can be found exactly at the intersection of entrepreneurship, financial management and ICT skills. Through a questionnaire-based survey conducted as part of a large transnational study ${ }^{1}$, the authors examine the financial management practices in ICT context among Croatian entrepreneurs. The findings reveal a number of peculiar patterns, such as relatively low understanding of basic financial management concepts, low ICT use and overreliance on specific sectors.

This study contributes to the growing entrepreneurship literature in three important ways. First, it examines the trilateral interdependencies arising from the interaction of entrepreneurship, financial management and ICT. Since smart ICT use itself is a relatively new development, the article offers novel and original insights into usage and new competence acquisition levels. Second, the study is focused on real-life applications and draws its strength from the practical aspects of starting and doing business. Third, it provides country-specific conclusions, which, in the case of Croatia are greatly needed in order to shed additional light into the intricacies of the domestic entrepreneurial activity. Its main weakness is the low sample number as the amount of data collected may limit or render any findings inconclusive. Nevertheless, this investigation is a step in the correct direction in terms of quantifying and mapping the levels of knowledge, skills, and competences necessary to propel Croatian entrepreneurs onto the European, and even global, scene. 
This article is structured as follows: Section 1 provides the general introduction to the topic. Section 2 discusses the literature pertaining to financial management practices and ICT use. Section 3 introduces the methodology and discusses the obtained findings, while Section 4 concludes.

\section{Literature Review}

Based on an ever-growing academic literature and empirical evidence, the belief that the entrepreneurial sector is a significant contributor to economic growth has entered the educational mainstream, becoming a universally-accepted theory (Willis, 2011). Some recent studies corroborate this claim in various contexts, ranging from geographic proximity and agglomeration (Presutti, Boari, and Majocchi, 2013), innovation capacity (Forsman, 2011; Fuellhart and Glasmeier, 2003), social value and capital (McKeever, Anderson, and Jack, 2014; Narangajavana et al., 2016), business networks (Bryson, Wood, and Keeble, 1993; Batillana, and Casciaro, 2012), etc.

Therefore, in order to increase entrepreneurial activity, one needs to first understand what makes it tick. Storey (1994) made the first comprehensive attempt to analyze the formation, development, contribution, and management of small firms in the UK. Since then, numerous studies have tried to pinpoint the various factors affecting entrepreneurship. Aaltonen distilled over 2000 articles from 60 top-tier journals in order to identify the ten generic factors that shape entrepreneurship: knowledge, learning, and resource acquisition are cited as the second most important (2016).

The significance of entrepreneurial competencies for business performance cannot be overstated, as numerous studies demonstrate (Faggian and McCann, 2009; Mitchelmore and Rowley, 2010). The human capital generated by the entrepreneurs' competencies is represented through education, experience, skills, genetics and attitudes of the owner and his employees (Bontis, Chua Chong Keow, and Richardson, 2000). Given how entrepreneurs often start their business by themselves, they require an array of skills to sustain them until other could be brought aboard in order to share the burden. Analyses by Lichtenstein and Lyons $(1996,2001)$ had identified a particular set of seventeen skills which were further explored by Smith, Schallenkamp, and Eichholz (2007). Financial skills, including accounting, budgeting, and managing financial resources, were placed in the category of Managerial skills and considered 'critical' to the success of the business venture.

Despite the increased traction financial competencies have received, there is very limited literature on the subject. Most succinctly, Chittenden, Poutziouris, and Michaelas assert that "studies of the reasons for small business failure inevitably show poor or careless financial management to be the most important cause" (1999, p.5). Nevertheless, the adoption of financial management practice among entrepreneurs 
remains shrouded in mystery, save some isolated attempts in the UK (Sian and Roberts, 2009), Greece (Daskalakis, Jarvis, and Schizas, 2013), Ghana, (Agyei, 2014), and Ethiopia (Dinka, 2017). The evidence presented by Deakins, Morrison, and Galloway (2016) suggests that financial management practices in small firms "need to be seen as evolving dynamic processes", a claim the corroborates the necessity for the research conducted in this article.

Finally, ICT use in a financial context has been rarely explored in a scientific manner thus far, with the most relevant research for Croatia conducted by Baldigara, Štambuk, and Mamula, which explored the internet usage evolution in a quantitative manner (2012).

\section{Data and Methodology}

For the purpose of the needs validation phase in the "Business Check Application" project, as well as this article, a survey targeting Croatian entrepreneurs was conducted over a two-month period (February-March) in 2018. The survey was carried out by means of a structured questionnaire, where all participants were chosen randomly, while the survey results were collected both online and in person. Out of 200 distributed questionnaires, 58 were returned with valid results (29\% response rate). The main limitation of the survey was the short time available for data collection.

The survey was designed to capture and describe the financial practices of entrepreneurs in Croatia. The questionnaire itself consists of 26 questions, broken down in five sections: Personal and demographic; Budgeting; Finance; Cash flow management; and ICT-enabled Business development. The structure of the questionnaire was developed following a preliminary survey among a smaller sample of entrepreneurs asked to identify the areas where they believe their competencies could gain the most from improvement. With regards to question types employed in the survey, 22 were multiple-choice, two were dichotomous, one was open-ended, while another was designed as a Likert-scale. In order to check if the questions correctly captured all of the available responses, most of the multiple questions contained the additional option of selecting 'Other' which allowed the respondents some freedom to provide their own qualitative answers that they considered could give a better or more precise answer than the one already suggested.

The statistical analysis provided in this work is mainly based on descriptive statistics given the cross-sectional nature of the data and the relatively small sample size. All of the calculations presented in the following tables were the authors' own. 


\section{Results and Discussions}

The objective of the questions delivered in the first section was to investigate the demographic structure of the respondents and provide a general overview of the size and types of businesses in which the Croatian entrepreneurs operate. A total of six questions was distributed in the first part aiming to provide a general impression of the respondents and the sectors in which they operate.

The first question asked for the age of the respondents. As is evident in Table 1, there is a large variation in age among the respondents, ranging from 17 to 60 . The average age of the Croatian entrepreneur is 40 years, while the median at 39,5 years is very close, signifying an even age distribution.

Table 1: Descriptive statistics on age of entrepreneurs

\begin{tabular}{|c|c|c|c|c|c|c|}
\hline Min. Age & Max. Age & Range & Mean & Median & Mode & Standard Deviation \\
\hline 17 & 60 & 43 & 40,78 & 39,5 & 47 & 9,382 \\
\hline
\end{tabular}

In order to give a better overview of the frequency of age distribution, Table 2 demonstrates that age-wise, the most populated sample bracket is the one between 30 and 40 years, with $43 \%$ of all of the repondents falling in that category.

Table 2: Age of entrepreneurs and share in sample

\begin{tabular}{|c|c|c|c|}
\hline Age/Years & Frequency & Valid Percent & Cumulative Percent \\
\hline$<20$ & 1 & 2 & 2 \\
\hline $20-30$ & 6 & 10 & 12 \\
\hline $30-40$ & 25 & 43 & 55 \\
\hline $40-50$ & 17 & 29 & 84 \\
\hline $50-60$ & 9 & 16 & 100 \\
\hline$>60$ & 0 & 0 & 100 \\
\hline Total & 58 & 100 & 100 \\
\hline
\end{tabular}

The second question inquired about the gender of the respondents. Although this was the only dichotomous question, the responses nevertheless provided the first surprise in the data, since $55 \%$ of the respondents answered that they were female, as shown in Table 3. 
Table 3: Gender of entrepreneurs and share in sample

\begin{tabular}{|c|c|c|c|}
\hline Gender & Frequency & Valid Percent & Cumulative Percent \\
\hline Male & 26 & 45 & 45 \\
\hline Female & 32 & 55 & 100 \\
\hline Total & 58 & 100 & 100 \\
\hline
\end{tabular}

The third question attempted to identify the country of origin of the entrepreneurs. While all of them had chosen Croatia, Table 4 shows that several respondents had selected an additional country, hence the larger sample size. While relatively small, this percentage of other countries represented in the sample demonstrates the global forces that shape business today.

Table 4: Country of origin and share in sample

\begin{tabular}{|c|c|c|c|}
\hline Country & Frequency & Valid Percent & Cumulative Percent \\
\hline Croatia & 58 & 92 & 92 \\
\hline USA & 2 & 3.2 & 95.2 \\
\hline UK & 1 & 1.6 & 96.8 \\
\hline UAE & 1 & 1.6 & 98.4 \\
\hline Iran & 1 & 1.6 & 100 \\
\hline Total & 63 & 100 & 100 \\
\hline
\end{tabular}

The fourth questions inquired about the number of years that the entrepreneurs have been running their businesses. It is visible in Table 5 the largest number of enterprises (64\%) have been in existence for over 4 years. While this may be a good signal in terms of business survival rates, it can also indicate low nascent entrepreneurial activity.

Table 5: Number of years the business is running

\begin{tabular}{|c|c|c|c|}
\hline Years & Frequency & Valid Percent & Cumulative Percent \\
\hline$<1$ & 4 & 7 & 7 \\
\hline $1-2$ & 11 & 19 & 26 \\
\hline $3-4$ & 6 & 10 & 36 \\
\hline$>4$ & 37 & 64 & 100 \\
\hline Total & 58 & 100 & 100 \\
\hline
\end{tabular}

The number of employees was investigated in the fifth question, giving a fairly good glimpse of the size of the companies and their employment levels. Table 6 displays the evidence present in the data, once again supporting the claim that small businesses are the most numerous employers within the economy, since $71 \%$ of the respondents had no more than 5 employees working for them, most often themselves included. 
Table 6: Number of employees

\begin{tabular}{|c|c|c|c|}
\hline Employees & Frequency & Valid Percent & Cumulative Percent \\
\hline $1-5$ & 41 & 71 & 71 \\
\hline $6-10$ & 6 & 10 & 81 \\
\hline $11-20$ & 7 & 12 & 93 \\
\hline $21-49$ & 2 & 3 & 96 \\
\hline $50-100$ & 1 & 2 & 98 \\
\hline$>100$ & 1 & 2 & 100 \\
\hline Total & 63 & 100 & 100 \\
\hline
\end{tabular}

The last question in this section inquired about business area in which the companies operate. This question allowed the respondents to add another business area in case they could not identify closely enough with the suggested answers. Table 7 provides the six most popular answers that capture approximately $57 \%$ of all the responses gathered, the rest being fragmented into smaller industries. Even more interestingly - though not surprisingly - Tourism tops the list, despite having been omitted from the original multiple-choice answers. Instead, the respondents had used the 'Other' option to influence the survey and include the sector they felt best represented their area of business.

Table 7: Most popular sectors for entrepreneurs

\begin{tabular}{|l|c|c|c|}
\hline \multicolumn{1}{|c|}{ Employees } & Frequency & Valid Percent & Cumulative Percent \\
\hline Tourism & 10 & 17 & 17 \\
\hline Other & 7 & 12 & 29 \\
\hline Business consultancy & 6 & 10 & 39 \\
\hline Technology & 5 & 8 & 47 \\
\hline $\begin{array}{l}\text { Accounting/Financial } \\
\text { services }\end{array}$ & 3 & 5 & 52 \\
\hline Education & 3 & 5 & 57 \\
\hline Total & 34 & 57 & 57 \\
\hline
\end{tabular}

The aim of the second section was to delve deeper into budgeting practices adopted by the respondents. Consisting of four multiple questions in total, this part of the survey was designed to investigate the manner and frequency with which company's budget is created, as well as to identify the person in charge of it and the tool most frequently used for liquidity management.

The first question inquired about identifying the person in charge of cash budgeting in the company. The results presented in Table 8 show that the entrepreneurs themselves, $76 \%$ of the time, are the ones taking care of liquidity management, which is only logical given that these enterprises operated at a micro level with very limited resources in terms of employees. Very little room is given to either internal or external accountants to influence this decision. The option 'Other' mainly contained combinations of some of the above answers. 
Table 8: Person in charge of cash budgeting

\begin{tabular}{|l|c|c|c|}
\hline \multicolumn{1}{|c|}{ Profile } & Frequency & Valid Percent & Cumulative Percent \\
\hline Entrepreneur & 44 & 76 & 76 \\
\hline Internal accountant & 3 & 5 & 81 \\
\hline External accountant & 2 & 3 & 84 \\
\hline Other & 9 & 16 & 100 \\
\hline Total & 58 & 100 & 100 \\
\hline
\end{tabular}

In terms of cash budgeting methods that are most often used among the entrepreneurs, Table 9 presents the options that were given to the respondents. It is interesting to note that $70 \%$ of them are acquainted with and use some type of a computerized program to manage their liquidity. Another revelation are the answers most often found under 'Other', where 8 out of 9 respondents, or $12.7 \%$ of the total sample admitted to not creating a cash budget at all, thus demonstrating a very high polarization between those who have acquired the necessary skills and those who, most likely, do not understand the concept of cash budgeting.

Table 9: Liquidity management methods employed

\begin{tabular}{|l|c|c|c|}
\hline \multicolumn{1}{|c|}{ Methods } & Frequency & Valid Percent & Cumulative Percent \\
\hline Excel spreadsheets & 26 & 41 & 41 \\
\hline $\begin{array}{l}\text { Fully computerized } \\
\text { accounting system }\end{array}$ & 18 & 29 & 70 \\
\hline Manual cash book & 6 & 10 & 80 \\
\hline $\begin{array}{l}\text { Copying receipts and } \\
\text { invoices }\end{array}$ & 4 & 6 & 86 \\
\hline Other & 9 & 14 & 100 \\
\hline Total & 63 & 100 & 100 \\
\hline
\end{tabular}

The third question inquired about the specific ICT tools that entrepreneurs use or are familiar with, where again a significant majority pointed to Excel (61\%). The results are summed up in Table 10, and again $15 \%$ of the respondents admitted not using or being familiar with any of the offered options.

Table 10: Levels of faimiliarity and use of ICT tools

\begin{tabular}{|l|c|c|c|}
\hline \multicolumn{1}{|c|}{ ICT tools/programs } & Frequency & Valid Percent & Cumulative Percent \\
\hline Excel & 43 & 61 & 61 \\
\hline ERP & 5 & 7 & 68 \\
\hline SAP & 4 & 6 & 74 \\
\hline Ciel & 1 & 1 & 75 \\
\hline None & 11 & 15 & 90 \\
\hline Other & 7 & 10 & 100 \\
\hline Total & 71 & 100 & 100 \\
\hline
\end{tabular}


The last question in this section examined the frequency with which the cash budget is being updated. Almost one third of the respondents reported updating their cash budget on a monthly basis, closely followed in frequency of answers with a quarterly update. Again, the section 'Other' contains an interesting revelation, where 5 respondents $(8.62 \%)$ of the total admitted to not updating their liquidity management system at all.

Table 11: Liquidity management frequency

\begin{tabular}{|l|c|c|c|}
\hline $\begin{array}{c}\text { Frequency of cash budget } \\
\text { update }\end{array}$ & Frequency & Valid Percent & Cumulative Percent \\
\hline Daily & 5 & 9 & 9 \\
\hline Weekly & 12 & 21 & 30 \\
\hline Monthly & 18 & 31 & 61 \\
\hline Quarterly & 16 & 28 & 89 \\
\hline Yearly & 1 & 1 & 91 \\
\hline Other & 6 & 10 & 100 \\
\hline Total & 58 & 100 & 100 \\
\hline
\end{tabular}

While very short, the third section looked into the financing practices of the entrepreneurs, especially with regards to the use of specific sources and the advice obtained prior to acquiring the funds for starting the business.

Table 12: Types of financial resources used

\begin{tabular}{|l|c|c|c|}
\hline \multicolumn{1}{|c|}{ Financial resources } & Frequency & Valid Percent & Cumulative Percent \\
\hline Own/family/friends & 43 & 52 & 53 \\
\hline $\begin{array}{l}\text { Venture capital/ } \\
\text { Accelerators }\end{array}$ & 0 & 0 & 53 \\
\hline Business angels & 1 & 1 & 54 \\
\hline EU funds/grants & 7 & 9 & 63 \\
\hline Bank loan & 23 & 28 & 91 \\
\hline Business incubators & 1 & 1 & 92 \\
\hline Crowdfunding & 1 & 1 & 93 \\
\hline Other & 6 & 7 & 100 \\
\hline Total & 82 & 100 & 100 \\
\hline
\end{tabular}

The first question presented in Table 12 asked the respondents to identify the types of resources used. Over half of the respondents said that they used their own, or their friends' or families' resources to start doing business. Moreover, in a bank-centric country such as Croatia, it was not surprising to see that traditional credit was by far the second most popular financial resource used.

The second question in this section delved deeper into the matter of obtaining relevant advice from other parties prior to starting the business venture. As evident in 
Table 13, the responses were evenly split, with one half of the respondents admitted to using some sort of external, while the other half conceding to using some sort of internal advice.

Table 13: Advice from other parties

\begin{tabular}{|l|c|c|c|}
\hline \multicolumn{1}{|c|}{ Type of party } & Frequency & Valid Percent & Cumulative Percent \\
\hline External & 29 & 50 & 50 \\
\hline Internal & 29 & 50 & 100 \\
\hline Total & 58 & 100 & 100 \\
\hline
\end{tabular}

Consisting of 8 questions total, the fourth section examines cash flow management knowledge and practices. As the old adage claims, cash is the lifeblood of the business and the fuel that keeps the engine running. In the context of Croatia, this was corroborated by the authors' previous research (Karanović, Karanović, and Gnjidić, 2018).

The first question in this section inquired about the estimation methods used for cash flow. The results in Table 14 show that while $45 \%$ of the respondents named either their bookkeepers or accountants as people in charge of cash flow estimation, $36 \%$ of the total still relied on management's subjective estimates.

Table 14: Methods used in estimating cash flow

\begin{tabular}{|l|c|c|c|}
\hline \multicolumn{1}{|c|}{ Methods } & Frequency & Valid Percent & Cumulative Percent \\
\hline $\begin{array}{l}\text { Subjective estimates by } \\
\text { management }\end{array}$ & 21 & 36 & 36 \\
\hline $\begin{array}{l}\text { Consensus of expert } \\
\text { opinion }\end{array}$ & 4 & 7 & 43 \\
\hline $\begin{array}{l}\text { Computer simulation/ } \\
\text { Tool/Application }\end{array}$ & 5 & 9 & 52 \\
\hline Mathematical models & 0 & 0 & 52 \\
\hline Bookkeeper & 13 & 22.5 & 74.5 \\
\hline Accountant & 13 & 22.5 & 97 \\
\hline Other & 2 & 3 & 100 \\
\hline Total & 58 & 100 & 100 \\
\hline
\end{tabular}

Table 15 summarizes the results where the respondents were asked to identify with the sentence which most closely reflected their company's situation. Again, there is a divergence among the entrepreneurs, with $43 \%$ closely abiding with procedures, and another $40 \%$ with no standard procedures. 
Table 15: Sentence most closely describing situation in company

\begin{tabular}{|l|c|c|c|}
\hline \multicolumn{1}{|c|}{ The company: } & Frequency & Valid Percent & Cumulative Percent \\
\hline $\begin{array}{l}\text { Provides a standard } \\
\text { procedure for estimating } \\
\text { items such as taxes, } \\
\text { depreciation, and salvage } \\
\text { value }\end{array}$ & 25 & & \\
\hline $\begin{array}{l}\text { Has standard forms to } \\
\text { collect CF data and other } \\
\text { investment information }\end{array}$ & 8 & 14 & 57 \\
\hline $\begin{array}{l}\text { Requires the use of } \\
\text { a standard model for } \\
\text { forecasting CF }\end{array}$ & 2 & 3 & 60 \\
\hline $\begin{array}{l}\text { There is no standard } \\
\text { procedure for generating } \\
\text { CF information }\end{array}$ & 23 & & \\
\hline Other & 0 & 40 & 100 \\
\hline Total & 58 & 0 & 100 \\
\hline
\end{tabular}

The third question posed the perpetual conundrum, which cash flow method was used, where the scales were firmly tipped in favor of the indirect method with $62 \%$. What is worrisome, however, is that Table 16 shows that $20 \%$ of the respondents answered with 'Other', a signal that they had no grasp of this basic accounting concept.

Table 16: Cash flow method used

\begin{tabular}{|l|c|c|c|}
\hline \multicolumn{1}{|c|}{ Method } & Frequency & Valid Percent & Cumulative Percent \\
\hline Indirect & 38 & 62 & 62 \\
\hline Direct & 11 & 18 & 80 \\
\hline Other & 12 & 20 & 100 \\
\hline Total & 58 & 100 & 100 \\
\hline
\end{tabular}

The next question inquired about the tools used for cash flow ratios, where $43 \%$ admitted that they used none. The other firmly favored Excel over other automated applications, with $31 \%$ and $21 \%$, respectively, as Table 17 shows.

Table 17: Tools used for $\mathrm{CF}$ ratio calculation

\begin{tabular}{|l|c|c|c|}
\hline \multicolumn{1}{|c|}{ Tool } & Frequency & Valid Percent & Cumulative Percent \\
\hline Excel spreadsheets & 18 & 31 & 31 \\
\hline $\begin{array}{l}\text { Automated system/tool/ } \\
\text { application }\end{array}$ & 12 & 21 & 52 \\
\hline None & 25 & 43 & 95 \\
\hline Other & 3 & 5 & 5 \\
\hline Total & 58 & 100 & 100 \\
\hline
\end{tabular}


Question 6 was perhaps the most provocative one, where the entrepreneurs were asked to reveal the funds they had so far invested in their business. While 9 of them refused to provide a figure, naming reasons such as confidential information or simply lack of knowledge, the rest were more forthcoming. Table 18 shows divergent answer, ranging from 0 to $15.000 .000 \mathrm{HRK}$. While the average is very high, at 977,417HRK, the median gives a more balanced view at 100.000 HRK invested.

Table 18: Amount of funds so far invested in business in HRK

\begin{tabular}{|c|c|c|c|c|c|c|}
\hline Min. amount & Max. amount & Range & Mean & Median & Mode & Standard Deviation \\
\hline 0 & 150000000 & 150000000 & 977417 & 100000 & 50000 & 2658432 \\
\hline
\end{tabular}

The next question inquired about the level of digitalization of invoicing. Table 19 presents the results, which show that $64 \%$ use fully electronic invoicing, yet there still remain $22 \%$ who rely on manual methods.

Table 19: Are invoices fully electronic?

\begin{tabular}{|l|c|c|c|}
\hline \multicolumn{1}{|c|}{ Answers } & Frequency & Valid Percent & Cumulative Percent \\
\hline Yes & 37 & 64 & 64 \\
\hline Sometimes & 8 & 14 & 78 \\
\hline Not electronic at all & 13 & 22 & 100 \\
\hline Total & 58 & 100 & 100 \\
\hline
\end{tabular}

The final question asked the respondents to identify certain e-invoicing tools and the respondents' knowledge was anecdotal at best, with only 5 respondents naming e-racun, and 2 naming Faros, a mere $12.1 \%$ of the total sample.

The last section is devoted to ICT-enabled business development and consists of 6 questions designed to map the entrepreneurs' ICT knowledge and associated competencies.

The first question asks about the use of procurement methods, and as can be seen in Table 19,57\% of the respondents don't have a system put in place, while the remainder rely on traditional methods. Practicing e-procurement has not been adopted by anyone yet.

Table 20: Use of procurement methods

\begin{tabular}{|l|c|c|c|}
\hline \multicolumn{1}{|c|}{ Method type } & Frequency & Valid Percent & Cumulative Percent \\
\hline E-procurement & 0 & 0 & 0 \\
\hline Traditional & 24 & 41 & 41 \\
\hline None & 33 & 57 & 98 \\
\hline Other & 1 & 2 & 100 \\
\hline Total & 58 & 100 & 100 \\
\hline
\end{tabular}


The second question asked the respondents to answer, in a qualitative way, to what extent they agreed with the claim that the integration of e-commerce can help the development of the company. Surprisingly, the disagreeing groups altogether make up almost one fifth of the entire sample; those are the entrepreneurs disinclined towards digitizing their businesses. The largest part, $31 \%$ of them, are undecided, while the remaining $50 \%$ finds e-commerce positive, as Table 20 shows.

Table 21: Do you agree that the integration of e-commerce can help company development?

\begin{tabular}{|l|c|c|c|}
\hline \multicolumn{1}{|c|}{ Answers } & Frequency & Valid Percent & Cumulative Percent \\
\hline Strongly disagree & 6 & 10 & 10 \\
\hline Disagree & 5 & 9 & 19 \\
\hline Neither agree nor disagree & 18 & 31 & 50 \\
\hline Agree & 13 & 22 & 72 \\
\hline Strongly agree & 16 & 28 & 100 \\
\hline Total & 58 & 100 & 100 \\
\hline
\end{tabular}

The third question asked to identify the e-commerce platform entrepreneurs use, or would like to use. While individual answers included some well-known names, two thirds of the respondents admitted to using, or wanting to use, none, as Table 21 shows.

Table 22: E-commerce platforms in use

\begin{tabular}{|l|c|c|c|}
\hline \multicolumn{1}{|c|}{ E-commerce } & Frequency & Valid Percent & Cumulative Percent \\
\hline Magento & 3 & 5 & 5 \\
\hline Shopify & 6 & 9 & 14 \\
\hline Sellr & 1 & 2 & 16 \\
\hline WooCommerce & 3 & 5 & 21 \\
\hline None & 43 & 67 & 88 \\
\hline Other & 8 & 12 & 100 \\
\hline Total & 64 & 100 & 100 \\
\hline
\end{tabular}

The answers to the following two questions are summarized in Table 22 and investigate the respondents' habits in terms of both buying and selling online. While a significant majority of the surveyed entrepreneurs has never sold anything online (59\%), one third of the same sample answered that they have nonetheless purchased something, thus revealing that a conversion process towards e-commerce has started, but is lacking a critical mass. 
Table 23: How often do you sell/purchase online?

\begin{tabular}{|l|r|r|r|r|r|r|}
\hline \multirow{2}{*}{ Per month } & \multicolumn{2}{|c|}{ Frequency } & \multicolumn{2}{c|}{ Valid Percent } & \multicolumn{2}{c|}{ Cumulative Percent } \\
\cline { 2 - 7 } & Buy & Sell & Buy & Sell & Buy & Sell \\
\hline$<1$ & 19 & 6 & 33 & 10 & 33 & 10 \\
\hline 1 & 12 & 3 & 21 & 5 & 54 & 15 \\
\hline $2-4$ & 7 & 3 & 12 & 5 & 66 & 20 \\
\hline$>5$ & 4 & 7 & 7 & 12 & 73 & 32 \\
\hline Never & 13 & 34 & 22 & 59 & 95 & 91 \\
\hline Other & 3 & 5 & 5 & 9 & 100 & 100 \\
\hline Total & 58 & 58 & 100 & 100 & 100 & 100 \\
\hline
\end{tabular}

The last question asked the respondents to identify the e-commerce platforms that they used the most. As expected, Amazon and e-bay topped the list. Still, the levels of their use shown in Table 23 are only marginally higher than the opposite camp who use none, demonstrating again that a significant portion of the entrepreneurs is lagging behind in online habits adoption.

Table 24: From which e-shop do you buy the most?

\begin{tabular}{|l|c|c|c|}
\hline \multicolumn{1}{|c|}{ Platform } & Frequency & Valid Percent & Cumulative Percent \\
\hline Amazon & 11 & 19 & 19 \\
\hline E-bay & 13 & 23 & 42 \\
\hline E-shop & 5 & 9 & 51 \\
\hline Skroutz/Etsy/Buyylo & 0 & 0 & 0 \\
\hline None & 22 & 38 & 99 \\
\hline Other & 6 & 11 & 100 \\
\hline Total & 58 & 100 & 100 \\
\hline
\end{tabular}

While very dense, the information extracted from the data display some patterns which shed light into the rarely explored world of entrepreneurs' financial knowledge and practices.

\section{Concluding Remarks}

The purpose of this paper was to present and interpret the results on the financial management practices among Croatian entrepreneurs in relation to budgeting, raising capital, cash flow management, and the use of ICT tools for enhanced efficiency of their businesses. The data was obtained for a sample of 58 entrepreneurs whose answers provide a valuable insight into their grasp of financial concepts in the context of smart ICT use. Following are some of the most interesting conclusions reached by the authors: 
From a demographic point of view, the typical Croatian entrepreneur is on average 40 years old, more likely to be female rather than male, has been in the business for more than 4 years, is employing no more than 5 people and has a relatively low grasp of financial concepts, especially in the context of smart ICT use. In terms of financial resources, the Croatian entrepreneur has invested approximately 100.000 HRK in starting their business, the initial capital most likely coming from their own, friends' or families' pockets, with bank loans frequently used to support the operations. When financing practices are concerned, the respondents' answers show that they know relatively little about the financial concepts they are expected to implement on a daily basis. This is rather worrisome as it demonstrates that there exists a gap in both awareness of the importance and the understanding of financial concepts and practices. From an ICT use point of view, the entrepreneurs don't nearly use the full potential that digitalization offers. This means that they are completely unaware of the possibilities for improved business efficiency. While the conversion process to digitalization is underway, there still lacks a critical mass to provide the impetus for catching up with the EU digital index average.

Finally, this study once again shows that the defining feature of the Croatian entrepreneurs is overreliance, both from a macroeconomic perspective as most of them work in the Tourism sector, and personally, as they rely primarily on their own knowledge and experience, occasionally involving the accountants in the financial decision making process and preferring to do everything themselves.

This research is not without its flaws, however. The biggest one stems from the fact that the time for data collection was limited, rendering a relatively small sample size. The results, while valuable, may not be sufficiently robust to sustain the test of time. Nevertheless, it is the authors' view that this article has moved the boundaries of research in both entrepreneurship and finance in the right direction and will provide the academic community with additional insight about Croatia. Most importantly, however, the promise of this study lies in the fact that it was replicated in other 5 countries as part of the transnational membership, leaving a much larger pool of unexplored data that may be used for future research on the topic.

\section{NOTES}

${ }^{1}$ The data were collected as part of the "Business Check Application" project in the field of vocational training and education, for which financial support was generously provided by the Erasmus+ Programme of the European Union (grant 2017-1-FR-01-KA202-037349). 


\section{REFERENCES}

Aaltonen, A., 2016. Factors Shaping Entrepreneurial Ecosystems and the RIse of Entrepreneurship: A View from Top Management Journals, Helsinki: Demos.

Agyei, K. N., 2014. Small Scale Business Practice of Basic Financial Management With Regards to Liquidity. International Journal of Research In Social Sciences, 4(5), pp. 77-85.

Baldigara, T., Štambuk, A. \& Mamula, M., 2012. An Insight into the Internet Usage Evolution - A Quantitative Approach. Lovran, International Federation of Communication Associations, pp. 136-150.

Battilana, J. \& Casciaro, T., 2012. Change Agents, Networks, and Institutions: A Contingency Theory of. Academy of Management Journal, 55(2), pp. 381-398.

Bontis, N., Chua Chong Keow, W. \& Richardson, S., 2000. Intellectual Capital and Business Performance in Malaysian Industries. Journal of Intellectual Capital, 1(1), pp. 85-100.

Bryson, J., Wood, P. \& Keeble, D., 1993. Business Networks, Small Firm Flexibility and Regional Development in UK Business Services. Entrepreneurship \& Regional Development, 5(3), pp. 265-278.

Chittenden, F., Poutziouris, P. \& Michaelas, N., 1999. Financial Management and Working Capital Practices in UK SMEs, Manchester: Manchester Business School.

Collins, J. \& Jarvis, R., 2002. Financial Information and the Management of Small Private Companies. Journal of Small Business and Enterprise Development, 9(2), pp. 100-110.

Daskalakis, N., Jarvis, R. \& Schizas, E., 2013. Financing Practices and Preferences for Micro and Small Firms. Journal of Small Business and Enterprise Development, 20(1), pp. 80-101.

Deakins, D., Morrison, A. \& Galloway, L., 2002. Evolution, Financial Management, and Learning in the Small Firm. Journal of Small Business and Enterprise Development, 9(1), pp. 7-16.

Dinka, S. T., 2017. Assessment of Financial Management Practices: A Case Study on Small Businesses in Sokoru District, Ethiopia. Research Journal of Finance and Accounting, 8(19), pp. $18-29$.

Faggian, A. \& McCann, P., 2009. Human Capital and Regional Development. In: R. Capello \& P. Nijcamp, eds. Handbook of regional growth and development theories. Cheltenham: Elgar, pp. 133-151.

Flash Eurobarometer 354, 2012. Entrepreneurship in the EU and beyond, Brussels: European Commission.

Forsman, H., 2011. Innovation Capacity and Innovation Development in Small Enterprises. A Comparison between the Manufacturing and Service Sectors. Research Policy, 40(5), pp. 739-750.

Fuellhart, K. \& Glasmeier, A. K., 2003. Acquisition, Assessment and Use of Business Information by Small-and Medium-sized Businesses: A Demand Perspective. Entrepreneurship \& Regional Development, 15(3), pp. 229-252.

Karanović, G., Karanović, B. \& Gnjidić, M., 2018. Liquidity Risk Management: Practice Among Croatian Firms. Zbornik Veleučilišta u Rijeci, 6(1), pp. 81-98.

Maxwell, S. \& Stone, D. L., 2004. Global Knowledge Networks and International Development. New York: Routledge.

Mitchelmore, S. \& Rowley, J., 2010. Entrepreneurial Competencies: a Literature Review and Development Agenda. International Journal of Entrepreneurial Behaviour \& Research, 16(2), pp. 92-111.

Narangajavana, Y., Gonzalez-Cruz, T., Garrigos-Simon, F. J. \& Cruz-Ros, S., n.d.

Presutti, M., Boari, C. \& Majocchi, A., 2013. Inter-organizational Geographical Proximity and Local Start-ups' Knowledge Acquisition: A Contingency Approach. Entrepreneurship \& Regional Development: An International Journal, 25(5-6), pp. 446-467. 
Rogers, S., 2009. Entrepreneurial Finance: Finance and Business Strategies for the Serious Entrepreneur. 2nd ed. New York: McGraw-Hill .

Sian, S. \& Roberts, C., 2009. UK small owner-managed businesses: accounting and financial reporting needs. Journal of Small Business and Enterprise Development, 16(2), pp. 289-305.

Smith, W. L., Schallenkamp, K. \& Eichholz, D. E., 2007. Entrepreneurial Skills Assessment: An Exploratory Study. International Journal of Management and Enterprise Development, 4(2), pp. 179-201.

Willis, K., 2011. Theories and Practices of Development. New York: Taylor \& Francis. 